\title{
Antara Hukum Islam dan Adat; Sistem Baru Pembagian Harta Warisan
}

Oleh

\section{Fatahuddin Aziz Siregar}

Dosen Fakultas Syariah dan Ilmu Hukum IAIN Padangsidimpuan

email : fatahuddinazizsiregar@iain-padangsidimpuan.ac.id

\begin{abstract}
Abstrac
The South Tapanuli community adopts a patrilineal kinship system so that women do not get inheritance, even if there is acquisition of property, women receive it not in their capacity as heirs but in the form of holong ni ate as confirmed in the Supreme Court Jurisprudence number 506K / Sip / 1968 dated January 22, 1969 However, on the other hand the Tapsel community underwent a process of Islamization that was quite deep, so that the customary law of South Tapanuli was also influenced by positive law including Jurisprudence which gave heir to girls later issued by the Supreme Court number 528K / Sip / 1972 dated 17 January 1973. This rule makes the practice of distributing the assets of Tapsel's community inheritance also shifts no longer according to the full provisions of adat law.

This paper focuses on answering the factors that cause the shift in Batak customary inheritance in Tapsel, how the form of Batak adat inheritance shifts in Tapsel, and how the role of Islamic law in the shifting Batak customary inheritance in Tapsel. To answer this, use descriptive-analytical field research using data collection techniques in the form of observations and interviews with traditional leaders, religious leaders, judges and the community who carry out the distribution of inheritance.

From this search, the authors found that the practice of inheritance in Tapsel society has shifted from adat inheritance caused by two factors, namely, First, the factor of Islamic law because Tapsel people have understood Islam well and run it in various fields of life including in the distribution of inheritance. Given that there are dozens of Islamic education institutions in Tapsel according to the author has given a pretty good understanding of Islamic law. So in general it can be said, that this change is a consequence of the Islamization process experienced by the Tapsel people. Second, is the factor of higher power or positive law because until now the community still believes that only the Religious Courts as a place to solve the problem of inheritance to obtain legal certainty.

The shift to adat inheritance occurs in several patterns. The first pattern is a total change from customary form to division according to faraid, this pattern occurs in areas that are fairly Islamic, namely the Mandailing Natal region, although of course there are some people who divide in a way that is not consistent in carrying out Islamic law. The second pattern is to carry out adat law, namely in communities that are relatively strict with adat, namely in the Padang Lawas and Sipirok regions, in this area many cases seem to have carried out faraid formally but the substance still reflects the spirit of adat law. The third pattern, namely the way of division which is a combination of Islamic law and customary law, which is a fairly moderate community in the Angkola region.

Islamic law has contributed by shifting the implementation of customary law to Islamic law. People who according to customary law do not receive inheritance become heirs who receive a certain portion. At first the mother did not count as an heir, then given a part 1/3 or
\end{abstract}


1/6. Istdri initially did not get any portion of the inheritance then received 1/4 or 1/8. Girls initially only have the status of olong ate, then receive a relatively large portion, which is $1 / 2$ or $2 / 3$.

Kata Kunci; Hukum, Islam, Adat, Harta, dan Warisan.

\section{A. Pendahuluan}

Sebelum dimekarkan, Tapsel adalah satu kabupaten di wilayah propinsi Sumatera Utara (Sumut) dengan ibu kota Padangsidimpuan, pada saat itu merupakan wilayah tingkat II yang terluas teritorinya diantara 17 kabupaten/kota, dengan luas sekitar $18.000 \mathrm{Km} 2$, dari keseluruhan luas wilayah Sumut, (71.000 Km2). Lalu sejak Agustus 2007 wilayah tersebut telah menjadi 4 kabupaten dan 1 kota, yaitu Kabupaten Tapsel, Kabupaten Mandailing Natal, Kabupaten Padang Lawas, Kabupaten Padang Lawas Utara, dan Kota Padangsidimpuan. Untuk menyebut kelima kabupaten/ kota tersebut lebih populer dengan istilah Tapanuli Bagian Selatan disingkat Tabagsel. Namun dalam penelitian ini tetap disebut istilah Tapanuli Selatan, yaitu masyarakat Adat dengan teritori mencakup 5 kabupaten/ kota sebagaimana tersebut di atas.

Etnis asli di wilayah ini adalah suku Batak Mandailing dan Angkola yang menganut sistem kekerabatan menurut garis keturunan ayah (patrilinial). Sistem kekerabatan patrilinial ini terlihat begitu dominan mewarnai sistem sosial komunitas secara keseluruhan, sampai sekarang sistem ini masih dianut masyarakat Tapsel, maka masyarakat Tapsel dapat dikatakan ketat dalam menjaga adat dan tradisi. Maka pada peristiwa-peristiwa penting, aturan dan tata cara adat masih dipraktikkan secara konsisten, misalnya pada acara horja (pesta) perkawinan aturan adat masih dilaksanakan oleh sebagian besar komunitas adat Tapsel.

Tanpa terkecuali menyangkut kewarisan, menurut sistem ini penerima bagian harta warisan adalah garis keturunan laki-laki sehingga kerabat perempuan tidak terhitung sebagai ahli waris. Sekalipun demikian, tidak berarti boru (anak perempuan) tidak memperoleh harta dari ayahnya, tetapi hukum adat tetap menyediakan instrumen lain yang disebut holong ni ate atau pangusayang berupa pemberian harta.

Pada era tahun 60-an dan 70-an, secara umum masyarakat mempraktikkan ketentuan hukum adat dengan ketat termasuk dalam melakukan pembagian harta warisan. Masyarakat adat di Padang Bolak misalnya menggunakan ketentuan hukum adat untuk membagi harta yang ditinggalkan oleh seorang pewaris. Pada masa itu harta peninggalan hanya jatuh ke 
tangan para kerabat laki-laki. Perempuan sama sekali tidak menerima bagian dari harta yang ditinggalkan oleh orang tuanya sendiri. Saat itu tidak ada anggota masyarakat yang merasa keberatan dengan cara pembagian yang berlaku secara umum tersebut. Mereka merasa bahwa memang demikianlah ketentuan baku yang berlaku dan harus dipatuhi sepenuhnya tanpa perlu dipertanyakan sama sekali. Masyarakat masih berpikir dan hidup secara sederhana dan penuh dengan suasana kebersamaan, sehingga tidak ada satupun individu yang merasa terusik dengan pembagian yang tidak berpihak kepada perempuan. Jumlah harta yang relatif sedikit merupakan faktor yang turut membuat suasana pembagian harta menjadi kondusif dan tidak berpotensi menimbulkan konflik. Hal senada juga disampaikan oleh Mangaraja Humala Oloan. Di daerah Mandailing yang terkenal sebagai wilayah yang kuat dan fanatik terhadap Islam, pada tahun 70-an juga masih mengacu kepada hukum adat dalam membagi harta warisan.

Yurisprudensi Mahkamah Agung bernomor 506K/Sip/1968 tertanggal 22 Januari 1969 telah memutuskan untuk tidak memberi bagian harta warisan kepada anak perempuan dengan merujuk kepada hukum adat yang berlaku di wilayah Tabagsel. Kemudian terjadi perubahan secara gradual, perempuan tidak lagi dipandang sebagai pihak yang hanya menerima bagian sekedar karena rasa iba dan belas kasihan. Hanya saja belum ada ukuran yang jelas tentang porsi bagian seorang anak perempuan. misalnya dalam suatu keluarga. Ada yang menyebut perbandingan 6:1 atau dengan rasio yang lain, sesuai dengan rasa kepantasan menurut ukuran masing-masing.

Dalam perkembangan selanjutnya, anak perempuan semakin mendapat tempat dan porsi yang jelas dalam pembagian harta warisan. Dalam berbagai kasus kewarisan yang diangkat ke ranah hukum, pihak ahli waris perempuan, terutama anak perempuan mendapat keputusan pengadilan yang mengapresiasi kedudukan mereka sebagai ahli waris. Suatu Yurisprudensi yang memberi kedudukan ahli waris bagi anak perempuan kemudian dikeluarkan oleh Mahkamah Agung dengan nomor 528K/Sip/1972 tanggal 17 Januari 1973. Ini menjadi suatu babak baru bagi sistem pembagian harta warisan di wilayah Tapsel pada waktu itu. Keputusan itu menandai perubahan yang lebih nyata dari sistem patrilinial yang tidak memberi bagian sama sekali dari harta warisan kepada anak perempuan, bergeser ke sistem parental-bilateral yang memperhitungkan dan memberi porsi bagian harta warisan kepada anak perempuan.

\section{B. Kajian Teoretis}


Membahas tema ini dimulai dengan melihat adat istiadat pada masyarakat Batak di Tapsel, dalam adat istiadat terkandung nilai budaya yang berfungsi sebagai pedoman, kemudian adat istiadat tersebut berubah dan menjadi sesuatu yang baru dengan nuansa agama (Islam) yang mempengaruhi keseluruhan sistem adat. Pada aspek hukum terjadi pergeseran sedemikian rupa yang diteropong dengan sosiologi hukum. Sisi hukum yang berubah menjadi lebih Islami dapat dijelaskan dengan teori perubahan hukum, dan secara utuh dijelaskan sebagai berikut:

1. Adat istiadat

Menurut Koentjaraningrat, adat istiadat mengandung suatu unsur terpenting, yaitu sistem nilai budaya. Hal ini disebabkan karena nilai-nilai budaya itu merupakan konsepkonsep mengenai apa yang hidup dalam alam pikiran sebagian besar dari warga suatu masyarakat mengenai apa yang mereka anggap bernilai, berharga, dan penting dalam hidup, sehingga dapat berfungsi sebagai suatu pedoman yang memberi arah dan orientasi kepada kehidupan para warga masyarakat tersebut. ${ }^{1}$

Meskipun nilai-nilai budaya berfungsi sebagai pedoman hidup manusia dalam masyarakat, tetapi sebagai konsep, suatu nilai budaya itu bersifat sangat umum dan berkenaan dengan ruang lingkup yang sangat luas, dan biasanya sulit diterangkan secara rasional dan nyata. Akan tetapi, karena sifatnya yang abstrak dan umum, membuat nilai tersebut berada dalam daerah emosional dari alam jiwa para individu yang menjadi warga dari kebudayaan yang bersangkutan. ${ }^{2}$

Sistem nilai budaya ini menjadi pedoman dan dasar bagi manusia mengenai; Pertama, hakekat dari hidup manusia. Kedua, hakekat dari karya manusia. Ketiga, hakekat dari kedudukan manusia dalam ruang dan waktu. Keempat, hakekat dari hubungan manusia dengan alam sekitarnya, dan Kelima, hakekat dari hubungan manusia dengan sesamanya.

Meskipun sulit diterangkan secara persis, penulis tetap mencoba mendeskripsikan mengenai sistem nilai budaya masyarakat Tapsel, yang menjadi unsur terpenting dari adat istiadat setempat, berdasarkan literatur yang terbatas dan tentu saja ditambah pemahaman penulis sendiri, yang kebetulan juga termasuk anggota komunitas dimaksud, terhadap dinamika kehidupan masyarakat. Pemahaman lebih difokuskan pada sistem nilai budaya sebagai pedoman bagi bidang terakhir dari kelima hal di atas, yaitu hakekat dari hubungan manusia dengan sesamanya, sebab menurut penulis titik sentral dari kelima hal tersebut adalah mengenai hakekat hubungan manusia dengan sesamanya. 
Pembahasan tentang adat istiadat masyarakat Tapsel tidak bisa lepas dari pembahasan adat Batak secara umum, sebab masyarakat Tapsel merupakan bagian dari masyarakat Batak, atau tepatnya sub suku Batak. Penduduk Tapsel umumnya merupakan anggota suku Batak Angkola dan sedikit Mandailing. ${ }^{3}$

Masyarakat Tapsel, sebagaimana suku Batak Iainnya, menghitung garis keturunan dari pihak laki-laki. ${ }^{4}$ Daerah pemukimannya disebut huta (desa). ${ }^{5}$ Huta ini mempunyai arti penting bagi masyarakat tersebut karena mengandung konsekwensi tertentu dalam struktur sosialnya. ${ }^{6}$

Mula pertama, beberapa keluarga menempati daerah tertentu yang lambat laun anggota masyarakatnya merasa perlu mengadakan sebuah pemerintahan resmi. Keseluruhan komunitas tersebut, yaitu anggota masyarakat dan tanah tempat bermukimnya itu kemudian disebut huta. Sebuah huta dikepalai oleh pamusuk atau lebih dikenal dengan Raja Pamusuk. Federasi beberapa huta atau disebut kuria dipimpin oleh seorang Panusunan Bulung yang dipilih dikalangan Raja Pamusuk. ${ }^{7}$ Raja Panusunan Bulung adalah primus inter pares $^{8}$, yang terutama diantara yang utama. Raja Panusunan Bulung dibantu oleh seorang wakil yang disebut Raja Pangundian yang berasal dari salah satu huta di wilayahnya.

Lazimnya, Panasunan Bulung diambil dari si suan bona bulu (pemuka huta) yang tertua yang bertugas sebagai namamulungi adat istiadat (yang melakukan kewajiban adat istiadat). Di wilayah kekuasaannya ia berkewajiban menjadi pengayom, tempat bertanya dan berlindung bagi masyarakat. Sebagaimana kepala-kepala rakyat lainnya di nusantara yang menjadi orang paling bertanggung jawab untuk menjamin terlaksananya hukum adat dengan baik, maka demikian pula halnya dengan kepala rakyat di Tapsel. Dalam kapasitasnya sebagai penanggungjawab dipatuhinya hukum ia disebut ompu ni saksi (yang menegakkan hukum). Ia dituntut mampu menguasai segala hal, yang dalam adat diistilahkan dengan mamboto harambir namuba sabut, babiat namuba bolang artinya ia mesti paham segala perubahan yang terjadi pada belang harimau. Dengan kata lain ia wajib menyimak segala denyut nadi kehidupan di wilayah kekuasannya, terutama yang berkaitan dengan perubahan yang terjadi khususunya dalam persoalan hukum adat. ${ }^{9}$ Sebelum penjajah Belanda datang dan menguasai semua sendi kehidupan masyarakat, di Tapsel terdapat 88 huta yang tertata dengan baik sesuai dengan hukum adat setempat. ${ }^{10}$

Satu hal penting dalam nilai budaya masyarakat Batak termasuk Tapsel adalah marga. ${ }^{11}$ Hal ihwal marga ini bagi masyarakat setempat demikian pentingnya dalam 
menempatkan diri secara pantas ketika berinteraksi dengan sesama anggota masyarakat. Di sebuah huta misalnya, marga (klan) sipungka huta (perintis didirikannya desa) yang kemudian menjadi Raja Pamusuk atau bahkan Raja Panusunan Bulung memiliki status sosial yang sangat tinggi di daerahnya, sehingga mesti diberi penghormatan tertentu dalam kehidupan sehari-hari. Apabila suatu huta dibuka oleh seseorang bermarga Harahap, maka di samping perintisnya menjadi Raja Pamusuk, seluruh anggota masyarakat bermarga Harahap mempunyai status tertinggi dibanding anggota masyarakat yang berasal dari marga lain. Kelompok marga yang membuka huta disebut harajaon (yang diperlakukan sebagai raja), marga pendatang disebut parripe dan menjadi hatobangon (kaum yang dituakan).

Dalam aturan adat masyarakat Batak marga diperoleh dari bapak, suatu ketentuan yang linier dengan sistem kekerabatan patrilineal. Ada beberapa alasan yang melatar belakangi timbulnya marga, yaitu:

a. Alasan sosial untuk berhubungan antara satu kesatuan dengan lainnya di bidang sosial;

b. Alasan perkawinan. Azas perkawinan eksogami menuntut dilakukannya perkawinan antar marga, perkawinan sesama marga menjadi sesuatu yang terlarang;

c. Alasan untuk membentuk klasifikasi golongan menurut adat. ${ }^{12}$

Sedemikian pentingnya makna marga dalam adat istiadat masyarakat Batak, menimbulkan sebuah kebiasaan martarombo, yaitu saling-menanyakan dan menelusuri garis keturunan yang didasarkan pada marga. Dalam sebuah perkenalan dengan sesama orang Batak pantun berikut menggambarkan dengan jelas kebiasaan tersebut jolo tinitip sanggar bahan huru-huruan, jolo sinuhun marga asa binoto partuturon artinya sudilah kiranya anda menyebutkan marga, agar (saya) tahu bagaimana mesti bertutur sapa.

Pantun di atas, sekaligus memperlihatkan betapa pentingnya bertutur sapa dengan tepat dalam tradisi masyarakat Batak yang disebut partururon. Partuturon dianggap sebagai barometer penguasaan dan penghayatan seseorang Batak terhadap adatnya. Menganggap sepi masalah partuturon, yang diindikasikan dengan bertutur sapa secara tidak tepat bisa membuat seseorang dicemooh sampai pada tingkat sangsi sosial tertinggi, yaitu dikucilkan dari pergaulan sehari-hari dan divonis sebagai seseorang naso mamboto tutur (tidak mengerti tutur), dan berpuncak pada naso mamboto adat (tidak tahu adat).

Partuturon di Tapsel pada azasnya hanya terdiri dari tiga tingkat, yaitu anak, ayah/ ibu dan kakek/ nenek. ${ }^{13}$ Namun bila dijabarkan secara detail, partuturon ini agak rumit 
dan menjadi kesulitan tersendiri bagi orang bukan Batak yang kemudian karena kontrak sosial tentu harus masuk menjadi bagian dari masyarakat Batak.

Partuturon mengacu pada suatu sistem kekerabatan yang bertumpu pada tiga sendi dasar yang disebut sebagai kuali besar maka dalihan na tolu merupakan tiga tungku yang menyangganya. Ungkapan berikut merepresentasikan bentuk hubungan antara ketiga unsur dalihan na tolu; "Manat Markahanggi, elek maranak boru, somba Marmora". Artinya bersikap teliti, hati-hati dan tenggang rasa terhadap kahanggi, pandai mengambil hati anak boru dan bersikap hormat terhadap mora.

Ketiga susunan ini mempunyai hubungan yang fungsional satu sama lain. Setiap pribadi Batak dapat menduduki status ketiga bentuk di atas, sesuai dengan suasana dimana ia menempatkan diri. Diantara ketiga posisi ini, yang bersifat tetap adalah kahanggi. Di luar itu ia dapat menjadi mora ataupun anak boru terhadap marga lain. Menyangkut hal ini Sutan Tinggibarani, seorang pemuka adat Tapsel mengatakan: masyarakat adat $i$ didirion diginjang ni hubungan kekeluargaan na tolu on. Onma na manjadi pundament ikatan kekeluargaan ni masyarakat adat $i^{14}$ (masyarakat adat ini didirikan di atas hubungan kekeluargaan dari ketiga bentuk ini. Ini merupakan fundamen dasar ikatan kekeluargaan dari masyarakat adat yang bersangkutan). Dalihan na tolu berperan secara efektif dalam kehidupan sosial masyarakat Tapsel. Segala bentuk persoalan biasanya diselesaikan dengan melibatkan ketiga unsur dalihan na tolu.

2. Pengaruh Islam

Sebelum datangnya Islam, masyarakat Tapsel adalah penganut animisme yang oleh penduduk setempat dinamakan Pelbegu. Pengaruh keyakinan lama ini bahkan masih terlihat dalam berbagai acara adat. Penyembelihan kerbau yang seringkali dilakukan baik pada acara siriaon (suka cita) seperti pesta penikahan maupun siluluton (duka cita) seperti kematian, biasanya didahului oleh sebuah seremoni somba-somba (menyembah kerbau yang akan disembelih).

Dibanding wilayah lain, terutama di daratan Sumatera, daerah Tapsel boleh dikatakan terlambat berkenalan dengan Islam. Namun, hal ini lebih disebabkan oleh letaknya yang secara geografis berada didaerah pedalaman yang sulit dijangkau, sehingga persentuhan dengan budaya Minangkabau dinyatakan bahwa adat manurun syara' manadaki. ${ }^{15}$ Artinya adat terbentuk dan melembaga di wilayah daratan yang arah penyebarannya kemudian menuju ke daerah pesisir (pantai), diistilahkan dengan manurun. Sebaliknya agama pertama sekali diterima oleh masyarakat yang bermukim di 
daerah pantai, selanjutnya menyebar ke daerah pedalaman. Meskipun ungkapan tersebut sesungguhnya diucapkan orang Minang menyangkut kasus yang terjadi di daerahnya, kiranya hal ini merupakan fenomena umum. Sebab saat itu transportasi memang menjadi kendala tersendiri dalam melakukan kontak sosial terlebih dengan masyarakat yang letaknya saling berjauhan.

Sekalipun islamisasi sudah sedemikian dalam, uniknya masyarakat Tapsel sedapat mungkin tetap setia terhadap nilai-nilai adat dan mempraktikkannya terutama dalam peristiwa-peristiwa penting dalam bentuk siriaon dan siluluton. Dan pada wilayahwilayah tertentu, masih melaksanakan ketentuan adat istiadat masih wajib dilaksanakan secara konsisten. Bahkan apabila tidak ditunaikan dengan baik, akan menjadi utang adat yang harus dilaksanakan pada suatu saat, ketika suatu keluarga yang terutang tersebut telah mampu menunaikannya.

Hanya saja, dalam masalah kewarisan terjadi pergeseran sistem yang cukup signifikan. Pola patrilinial yang menjiwai seluruh sistem hubungan keluarga dan kemasyarakatan dalam hal pembagian harta warisan bergeser ke arah parental-bilateral. Dari pengamatan penulis dapat diasumsikan bahwa pergeseran tersebut terjadi karena masyarakat Tapsel saat ini kurang percaya terhadap hukum adat sebab dirasa sudah tidak memenuhi rasa keadilan, bersifat diskriminatif dan melecehkan kaum perempuan. Akhirakhir ini, apabila terjadi sengketa pembagian harta warisan maka masyarakat lebih cenderung untuk menyelesaikannya melalui Pengadilan Agama.16

Situasi ini muncul sebagai akibat dari semakin baiknya pemahaman terhadap hukum Islam. Sehingga kondisi ini memunculkan semacam hipotesis bahwa jika pemahaman terhadap hukum Islam semakin baik maka masyarakat lebih memilih penyelesaian melalui Pengadilan Agama.

\section{Pergeseran Kewarisan di Tapanuli Selatan}

Pelaksanaan hukum Islam dengan memilih kasus pada pelaksanaan pembagian harta warisan, ditemukan bahwa ada 3 bentuk penyelesaian pembagian harta warisan, yaitu Faraid, kesepakatan dan hukum adat dengan warna Islam. Di wilayah Padang Lawas (Palas), khususnya Padang Lawas Utara (Paluta) yang dikenal masih kuat menjalankan adat, masyarakat mengaku membagi harta berdasarkan faraid.

Ketika ditelusuri lebih lanjut, pelaksanananya menunjukkan kepatuhan kepada faraid di permukaan, tetapi substansinya masih mencerminkan semangat hukum adat. Secara formal 
dikesankan sebagai faraid, karena telah memberi bagian kepada anak perempuan. Dapat dikatakan bahwa hampir tidak ada anak perempuan yang tidak mendapatkan bagian harta warisan, namun ternyata porsi bagiannya masih jauh lebih sedikit dibanding anak laki-laki. Idealnya menurut faraid anak perempuan menerima $1 / 2$ bagian dari anak laki-laki. Kelihatannya cara pikir dan pola tindak laku masyarakat masih berada di jagad patrilinial, padahal faraid menganut asas bilateral. Ada juga kasus pembagian harta warisan yang disebut masyarakat sebagai pelaksanaan faraid tetapi dengan pengaruh adat, yaitu memperhitungkan biaya horja yang kelak akan dikeluarkan untuk seorang anak laki-laki yang akan menikah sebelum membagi harta warisan. Pada Kasus lain, ketentuan adat yang mengharuskan seorang anak boru menaruh hormat kepada moranya telah menjadi penghalang pelaksanaan faraid. Seorang guru agama hadir dalam pembagian harta warisan mewakili ibunya. Kompisisi ahli waris adalah seorang anak laki-laki dan seorang anak perempuan. Secara faraid anak perempuan seharusnya menerima bagian sebesar $1 / 3$ harta warisan, anak laki-laki $2 / 3$. Sidang yang dihadiri oleh tokoh adat, dan tokoh agama kemudian memutuskan memberi bagian $1 / 8$ kepada anak perempuan, dan $7 / 8$ untuk anak laki-laki. Guru agama yang hadir mewakili ibunya yang berkedudukan sebagai ahli waris, yaitu anak perempuan, tidak berani menyampaikan ketentuan yang seharusnya karena menurut pengakuannya dia segan terhadap moranya. (Bisa kita bayangkan berapa ratus juta yang melayang karena segan terhadap mora tersebut).

Satu kasus menarik lain yang memperlihatkan betapa hukum adat masih kuat memperngaruhi cara pembagian harta warisan, seorang pewaris meninggal dunia dan meninggalkan ahli waris yang terdiri dari isteri, anak perempuan, dan 3 orang saudara lakilaki. Menurut faraid seharusnya anak perempuan mendapat $1 / 2$, isteri $1 / 8$ sisanya dibagi oleh 3 orang saudara. Tetapi karena keluarga tersebut tidak memiliki anak laki-laki, sehingga seperti tidak martondi dan diperlakukan semena-mena oleh 3 orang saudara laki-laki pewaris.

Sekalipun di wilayah ini adat masih terbilang kuat, setidaknya hukum Islam telah memberi pengaruh dan menggeser hukum adat sekalipun belum sepenuhnya ideal. Disamping itu tentu tetap ada anggota masyarakat yang sungguh-sungguh mentaati hukum kewarisan Islam.

Di wilayah Mandailing, masyarakat lebih mentaati faraid, namun keterbatasan pengetahuan menjadi penyebab faraid tidak terlaksana secara akurat, padahal para ahli waris telah memiliki kesadaran menjalankannya. Seorang pemuka agama menjelaskan bahwa patokan dalam pembagian harta warisan adalah 2 bagian untuk laki-laki dan 1 bagian untuk 
perempuan, berapapun jemlah mereka. Tentu ini penjelasan yang keliru dan bisa menyesatkan, bagaimana jika misalnya anak laki-laki jauh lebih banyak dibanding anak perempuan, katakanlah ada 5 anak laki-laki dan hanya 1 anak perempuan, maka akan terjadi ketidakadilan. Menariknya justru seorang tokoh adat, yaitu raja di Gunungtua Panyabaungan, terbilang cukup menguasai faraid.

Di Padangsidimpuan sebagai masyarakat urban yang lebih moderat berada di tengah dan menerapkan pembagian yang beragam. Tetapi pembagian menurut adat sudah dapat dikatakan tidak dilakukan lagi.

Secara umum dapat dikatakan bahwa kewarisan adat telah bergesar dan faktor yang menyebabkan pergeseran tersebut adalah hukum Islam. Pelakunya tentu adalah para tokoh agama yang memberi pemahaman, masyarakat sendiri yang semakin terdidik. Dan penting untuk disampaikan bahwa ternyata tokoh adat juga telah berkontribusi secara signifikan dalam mengawal pelaksanaan faraid/ hukum kewarisan Islam.

Satu hal menarik yang patut juga disampaikan adalah bahwa ketika masyarakat belum melakukan menurut ketentuan faraid secara rigid mereka merasa sedang melanggar hukum Islam. Artinya ini menjadi peluang tersendiri untuk meningkatkan kesadaran masyarakat melaksanakan hukum Islam. Faraid memang memilki beberapa asas, salah satunya adalah asas ijbary, yang menyatakan bahwa ketika seorang meninggal dunia maka secara otomatis telah terjadi peralihan hak milik dari pewaris kepada ahli waris, jadi perlihan itu bersifat memaksa. Namun memperhatikan beberapa ketentuan lain yang terkait, Prof Amir misalnya mengatakan bahwa kewarisan Islam lebih bersifat mengatur dibanding memaksa. Jadi jika ada keluarga yang telah teratur dengan sendirinya, maka pembagian harta warisan dianggap telah selesai dan memenuhi kehendak hukum Islam. Pendapat ini juga dianut dan diadopsi oleh Kompilasi Hukum Islam pasal 183 yang memberi alternatif penyelsaian pembagian harta warisan melalui jalan musyawarah.

Hukum resmi negara yang Islami dalm bentuk hukum material berupa KHI, dan hukum formal, yaitu UU No. 7 Thn 1989 dan duperkuat oleh UU No. 3 Thn 2006 tentang Perubahan UU No. 7 Thn 1989 tentang Peradilan Agama turut memperkuat hukum Islam termasuk dalam bidang kewarisan. UU terakhir ini bahkan telah menghilangkan hak opsi dalam penyelesaian sengketa kewarisan dan menganut asas personalitas keislaman. Maksudnya, kewarisan yang terjadi antara sesama warga beragama Islam harus diselesaikan menurut hukum Islam. Keinginan masyarakat untuk menerapkan hukum Islam dalam sengketa kewarisan terlihat pada jumlah kasus yang diterima, diperiksa dan diputuskan oleh 
Pengadilan Agama di Tapsel. Data perkara kewarisan di 3 Pengadilan Agama sebagai berikut:

Rekapitulasi Kasus Kewarisan di Pengadilan Agama di Wilayah Tapanuli Selatan Tahun 2012- Mei 2016

\begin{tabular}{|c|c|c|c|c|c|}
\hline No & Tahun & $\begin{array}{c}\text { Pengadilan Agama } \\
\text { Kota Padangsidimpuan }\end{array}$ & $\begin{array}{c}\text { Pengadilan Agama } \\
\text { Padangsidimpuan }\end{array}$ & $\begin{array}{c}\text { Pengadilan Agama } \\
\text { Panyabungan }\end{array}$ & Jumlah \\
\hline 1 & 2012 & 7 & 3 & 3 & 13 \\
\hline 2 & 2013 & 13 & 10 & 3 & 26 \\
\hline 3 & 2014 & 10 & 8 & 6 & 24 \\
\hline 4 & 2015 & 5 & 2 & 7 & 14 \\
\hline 5 & 2016 & 4 & 6 & 1 & 11 \\
\hline \multicolumn{2}{|c|}{ Jumlah } & 39 & 29 & 20 & $\mathbf{8 8}$ \\
\hline
\end{tabular}

Apabila kasus pada setiap Pengadilan Agama dibagi dengan persentase jumlah umat Islam di wilayah hukumnya maka akan diperoleh indeks sebagai berikut:

1. Pengadilan Agama Kota Padangsidimpuan

2. Pengadilan Agama Padangsidimpuan

3. Pengadilan Agama Panyabungan

$$
: 44,32: 14,59=3,03
$$

$$
: 32,95: 52,66=0,63
$$

$$
: 22,73: 32,75=0,69
$$

Dapat dibaca bahwa indeks tertinggi berada pada Pengadilan Agama Kota Padangsidimpuan dengan Indeks 3,03. Berbeda dengan presentase kasus di mana pada urutan kedua adalah Pengadilan Agama Padangsidimpuan, setelah dikonversi menjadi indeks, urutan kedua justru diraih Pengadilan Agama Panyabungan dengan indeks 0,69. Kemudian di urutan ketiga adalah Pengadilan Agama Padangsidimpuan dengan indeks 0,63.

Dapat dianalisis bahwa di satu sisi secara umum intensitas konflik dalam membagi harta warisan di daerah perkotaan terbilang tinggi. Artinya pembagian secara damai tidak dapat ditempuh. Karakter masyaraket perkotaan pada umumnya memang menunjukkan melonggarnya ikatan keluarga. Kemudahan hidup yang ditopang oleh kemampuan finansial di perkotaan membuat orang merasa dapat hidup sendiri tanpa memerlukan orang lain dan memuculkan sikap individualisme dan tidak peduli terhadap orang lain. Pola interaksi sosial lebih memperlihatkan faktor kepentingan individual.

Faktor hukum resmi negara ini sebtulnya dimaksudkan untuk memberi kepastian dan keadilan hukum. Namun ada tuduhan bahwa kehadiran hukum resmi negara ini telah menjadi pemicu timbulnya konflik di antara para ahli waris. Asumsi ini sekilas terlihat benar jika kita memperhatikan meningkatnya jumlah kasus kewarisan pasca lahirnya UU No. 3 Thn 2006. Seorang warga Hutaimbaru yang menjadi ahli waris dengah posisi sebagai anak laki-laki telah menuduh saudara perempuan kandungnya yang menuntut penyelesaian sengketa 
kewarisan melalui pengadilan, menuduh saudara perempuannya tersebut sebagai sombong dan memiliki beking sehingga saudaran kandungnya sendiri tidak dihormati lagi sebagai pihak mora.

Terkait hal ini terdapat juga sejumlah masyarakat, umumnya anak perempuan yang lebih memilih diam ketika saudara laki-lakinya menguasai seluruh harta yang ditinggalkan oleh orangtua mereka. Mereka beralasan bahwa dalam perjalanan kehidupannya akan selalu merasa butuh terhadap saudara laki-lakinya sebagai pihak mora yang memiliki kedudukan penting dalam berbagai upacara adat.

\section{Penutup}

Ada dua faktor yang telah menggeser praktik pembagian harta warisan secara adat, yaitu ; Pertama, hukum Islam yang semakin kuat mengakar dan telah merasuk ke dalam hati sanubari masyarakat mempengaruhi cara mereka membagi harta warisan. Menurut penulis pemahaman yang semakin baik dibentuk oleh pendidikan formal yang mereka tempuh di berbagai lembaga pendidikan seperti pondok pesantren dan madrasah. Di samping itu praktik pembagian harta warisan dilakukan di bawah bimbingan para tokoh agama. Menariknya para tokoh adat juga turut mendorong agar pembagian harta warisan dilakukan menurut ketentuan hukum Islam. Sebagian tokoh adat ada yang bahkan memiliki pengetahuan yang cukup tentang faraid, dan kalau tokoh tersebut memiliki pengetahuan yang terbatas dia akan menyarankan untuk membagi dengan arahan ulama. Faktor hukum Islam ini terlihat nyata di masyarakat. Secara formal masyarakat menggunakan istilah piraid (dialek setempat untuk menyebut faraid) dalam melakukan pembagian harta warisan. Kedua, hukum negara yang Islami. Kesadaran untuk melaksanakan ketentusan hukum Islam membuat masyarakat memilih Pengadilan Agama (PA) untuk menyelesaikan sengketa kewarisan yang terjadi jika penyelesian secara kekeluargaan tidak dapat ditempuh lagi. Dengan tujuan untuk mendapatkan kepastian hukum mereka mengajukan perkara kewarisan ke lembaga yang menerapkan materi hukum kewarisan Islam. Data statistik menunjukkan perkara kewarisan yang diperiksa dan diselesaikan oleh PA terus menunjukkan tren peningkatan. Ketika ada anggota masyarakat bersikukuh untuk tetap mempraktikkan hukum adat, sikap tersebut dikalahkan oleh berlakunya aturan imperatif perundang-undangan resmi negara. Masyarakat pencari keadilan benar-benar memanfaatkan pranata hukum ini untuk menyelesaikan persoalan yang muncul di lingkungan keluarganya ketika membagi harta warisan. Hukum negara dalam bidang kewarisan juga semakin menemukan eksistensinya yang menguat 
dengan regulasi yang lebih kuat. Fakta ini berimplikasi terhadap semakin ditinggalkannya ketentuan hukum adat.

Pergeseran kewarisan adat mengambil beberapa bentuk. Pada masyarakat yang terbilang Islami, yaitu wilayah Mandailing pergeseran yang terjadi adalah dari kewarisan adat menjadi kewarisan berdasarkan faraid. Masyarakat membagi harta dengan mematuhi ketentuan hukum Islam. Meskipun demikian tentu masih ada masyarakat yang membagi harta dengan tetap memprioritaskan anak laki-laki. Pada masyarakat yang relatif lebih ketat terhadap adat, yaitu di wilayah Padang Lawas dan Sipirok pembagiannya masih sangat dipengaruhi semangat hukum adat yang bertumpu kepada sistem kekerabatan patrilinial. Banyak kasus yang pada tataran permukaan seolah-olah telah melaksanakan faraid secara formal, namun substansinya masih mencerminkan semangat hukum adat. Pada masyarakat yang lebih moderat yaitu di wilayah Angkola Sipirok perubahannya lebih fleksibel. Sebagian sesuai faraid, sebagian lagi masih memprioritaskan anak laki-laki dan sebagian berdasarkan kesepakatan keluarga. Pada wilayah ini ada pengecualian untuk wilayah Sipirok yang terhitung masih ketat memberlakukan hukum adat termasuk praktik kewarisan, sehingga wilayah ini dapat dikatakan menerapkan cara yang sama dengan wilayah Padang Lawas. Cara pembagian harta warisan masih cenderung kepada ketentuan adat, namun telah mendapat sentuhan hukum Islam. Anak laki-laki menerima porsi bagian yang relatif jauh lebih besar dan melebihi rasio 2 berbanding 1. Masyarakatpun masih menggunakan istilah olong ate untuk menyebut bagian anak perempuan, namun dengan makna yang berbeda. Sekarang olong ate diasumsikan sebagai bagian anak perempuan, namun bagian tersebut bersifat wajib. Ini tentu berbeda dengan olong ate yang dimaknai oleh masyarakat pada zaman dahulu yang mengangagap olong ate sebagai pemberian sukarela yang bisa saja diberikan atau tidak diberikan kepada anak perempuan.

Hukum Islam telah berkontribusi mengubah cara pembagian menurut adat. Praktik pembagian harta warisan di masyarakat yang semula tidak memberi bagian kepada ibu, kemudian memberi porsi $1 / 3$ atau $1 / 6$ sesuai dengan kondisinya. Isteri yang semula tidak termasuk ahli waris, kemudian menerima bagian sesuai dengan ketentuan hukum Islam yang menetapkan bagian isteri 1/4 atau 1/8 sesuai dengan kondisi keluarganya. Anak perempuan semula hanya menjadi penerima olong ate kemudian menjadi ahli waris yang menerima bagian $1 / 2$ atau 2/3. Dengan demikian dapat disimpulkan lebih lanjut bahwa hukum Islam menjadi faktor utama dalam pergeseran hukum kewarisan adat Batak di Tapsel. Masyarakat Muslim Tapsel menyadari pentingnya memberlakukan hukum Islam sebagai ketentuan yang 
bernilai keadilan transendental. Sebagian besar memahami bahwa faraid adalah ketentuan yang bersifat memaksa, sehingga ketika belum dilaksanakan secara konsisten merupakan suatu bentuk pelanggaran. Sebagian lagi karena telah mendapat pencerahan dari orang yang memahami dengan baik bahwa sesungguhnya faraid lebih bersifat mengatur, mereka kemudian melakukan pembagian sesuai kondisinya berdasarkan kesepakatan. Pada skala nasional hukum Islam kemudian melalui proses legislai menjadi ketentuan perundangundangan resmi baik dalam bentuk hukum material maupun hukum formal sehingga menjadi suatu kekuatan tersendiri untuk memberlakukan hukum kewarisan Islam di wilayah Tapsel. Jika dibandingkan dengan komunitas non Muslim, perubahan serupa juga terjadi. Menyimak Jurisprudensi Mahkamah Agung dan penjelasan tokoh non Muslim, perubahan tersebut lebih diakibatkan tercederainya rasa keadilan masyarakat. Sekalipun terjadi perubahan yang sama, sehingga mengesankan perubahan tersebut lebih disebabkan oleh modernitas, peran hukum Islam tetap tidak dapat dinafikan. Pada komunitas Muslim hukum Islam adalah unsur modernitas itu sendiri. Pemahaman dan pelaksanaan yang dinilai mencerminkan semangat pembaruan dan pembaharuan adalah hukum Islam. Perubahan yang terjadi memperlihatkan karakteristik yang berbeda. Perubahan pada masyarakat Muslim diinisiasi oleh girah keagamaan yang memang membawa esensi pembaharuan. Sementara pada komunitas non Muslim disebabkan oleh kemauan untuk menerapkan cara baru yang berkeadilan. Hukum Islam juga telah mempengaruhi pranata kewarisan adat menjadi lebih Islami. Lembaga olong ate saat ini telah mendapat pemaknaan baru yang diinspirasi oleh konsep zawil arham. Olong ate menjadi solusi yang bersifat fleksibel. Bisa menjadi solusi untuk memberi bagian kepada ahli waris pengganti. Juga dapat menjadi bagian tambahan yang melengkapi bagian secara faraid untuk ahli waris perempuan.

Disarankan kepada masyarakat yang membagi harta warisan secara musyawarah untuk menjamin pembagian harta warisan berlangsung damai tidak menyisakan potensi konflik. Maka untuk peneliti selanjutnya, hendaknya melakukan penyelidikan ilmiah tentang tingkat kepuasan ahli waris, terutama ahli waris perempuan atas pembagian harta warisan di lingkungan keluarga.

Disarankan kepada tokoh adat agar dapat memberi teladan kepada masyarakat agar nilai-nilai luhur adat tetap dapat bertahan dan dihormati, dan pada urutannya dipraktikkan masyarakat Tapsel. Tokoh adat dituntut untuk mampu meneruskan keagungan adat dan mempersiapkan penerus yang memiliki kredibilitas di mata masyarakat. 


\section{DAFTAR PUSTAKA}

Koentjaraningrat, Pengantar Ilmu Antropologi, cet. Ke-8, Jakarta: Rineka Cipta, 1990.

Parlindungan, L.S Diapari Patuan Naga Humala,, Perkembangan Adat Istiadat Masyarakat Suku Batak Tapanuli Selatan: Suatu Tinjauan, ttp: Tnp. tt.

Khairuddin, Sosiologi Keluarga, Yogyakarta: Liberty, 1997.

Harahap, Baginda Raja Harahap,. Poda-poda ni Adat Dalihan Natolu Kekeluargaan ni Tapanuli Selatan, Padangsidimpuan: Pustaka Rahmat, tt.

Gunawan, Hendra, Sistem Peradilan Islam, pada Jurnal Yurisprudentia; Jurnal Hukum Ekonomi Syariah Fakultas Syariah dan Ilmu Hukum IAIN Padangsidimpuan, Volume 5 Nomor 1 Edisi Januari-Juni 2019.

R. Soepomo, Bab-bab Tentang Hukum Adat, cet, Ke-13, Jakarta: PT. Pradnya Paramita, 1993. Majalah Pengkajian Budaya Parmusa, (Parhorasan Nusantara), No.9/II/1997.

Tambunan, E.H.,. Sekelumit Mengenai Masyarakat Batak Toba dan Kebudayaannya Sebagai Sarana Pembangunan, Bandung: Tarsito, 1982.

Harahap, H.M.D.,. Adat Istiadat Tapanuli Selatan, Jakarta: Grafindo Utama, 1986.

Alam, CH. ST. Tinggibarani Perkasa dkk,. Burangir na Hombang, Padangsidimpuan: tn.p.1977.

Hamka, Islam dan Adat Minangkabau, cet. Ke-1, Jakarta: Pustaka Panjimas, 1984.

Wawancara dengan Syamsul Kamal Siregar, Tokoh Agama di Padangsidimpuan, pada hari Sabtu, 26 Maret 2016.

\section{End Note :}

${ }^{1}$ Koentjaraningrat, Pengantar Ilmu Antropologi, cet. Ke-8, (Jakarta: Rineka Cipta, 1990), h. 190.

${ }^{2}$ Ibid.

${ }^{3}$ Perlu diutarakan bahwa suku Batak terdiri dari Batak Toba, Dairi (Pakpak), Angkola, Mandalling, Karo dan Simalungun. Ada banyak perbedaan antara masing-masing sub suku ini, namun secara garis besar tetap dapat dilihat benang merah persamaannya. Lihat L.S Diapari Patuan Naga Humala Parlindungan, Perkembangan Adat Istiadat Masyarakat Suku Batak Tapanuli Selatan: Suatu Tinjauan, (ttp: Tnp. tt), h. 11.

${ }^{4}$ Khairuddin, Sosiologi Keluarga, (Yogyakarta: Liberty, 1997), h. 89. Lihat juga, Hendra Gunawan, Sistem Peradilan Islam, pada Jurnal Yurisprudentia; Jurnal Hukum Ekonomi Syariah Fakultas Syariah dan Ilmu Hukum IAIN Padangsidimpuan, Volume 5 Nomor 1 Edisi Januari-Juni 2019, h. 56-70.

${ }^{5}$ Baginda Raja Harahap, Poda-poda ni Adat Dalihan Natolu Kekeluargaan ni Tapanuli Selatan, (Padangsidimpuan: Pustaka Rahmat, tt), h. XVII

${ }^{6}$ Parsadaan Marga Harahap Dohot Anak Boruna, Op.cit. h. 19-22

${ }^{7}$ Ibid., h. 19

${ }^{8}$ Pemimpin yang terpilih karena kemampuan individual, bukan karena faktor keturunan.

${ }^{9}$ R. Soepomo, Bab-bab Tentang Hukum Adat, cet, Ke-13, (Jakarta: PT. Pradnya Paramita, 1993), h. 61.

${ }^{10}$ Majalah Pengkajian Budaya Parmusa, (Parhorasan Nusantara), No.9/II/1997, h. 25

${ }^{11}$ Marga selalu dicantumkan oleh orang Batak di belakang namanya, Misalnya Sahminan Siregar, yang berarti si Sahminan adalah keturunan bermarga Siregar.

${ }_{12}$ E.H. Tambunan, Sekelumit Mengenai Masyarakat Batak Toba dan Kebudayaannya Sebagai Sarana Pembangunan, (Bandung: Tarsito, 1982), h. 120

${ }^{13}$ H.M.D. Harahap, Adat Istiadat Tapanuli Selatan, (Jakarta: Grafindo Utama, 1986), h. 13

${ }^{14}$ CH. ST. Tinggibarani Perkasa Alam dkk, Burangir na Hombang, (Padangsidimpuan: tn.p.1977), h. 23

${ }^{15}$ Hamka, Islam dan Adat Minangkabau, cet. Ke-1, (Jakarta: Pustaka Panjimas, 1984), h.14

${ }^{16}$ Wawancara dengan Syamsul Kamal Siregar, Tokoh Agama di Padangsidimpuan, pada hari Sabtu, 26 Maret 2016. 